\title{
НЕЙРОПРОТЕКТОРНЫЙ ПОТЕНЦИАЛ ГИДРОКСАМОВЫХ КИСЛОТ, СОДЕРЖАЩИХ В КАЧЕСТВЕ САР-ГРУППЫ ПРИРОДНЫЕ ФРАГМЕНТЫ
}

\author{
М.Е. Неганова', Ю.Р. Александрова', Е.В. Суслов², Е.С. Можайцев², \\ А.А. Мункуев ${ }^{2}$, К.П. Волчо ${ }^{2}$, С.Г. Клочков' \\ ${ }^{1}$ ИФАВ РАН, 142432, Россия, Черноголовка, Северный пр., д. 1. \\ ${ }^{2}$ НИОХ СО РАН, 630090, Россия, Новосибирск, пр. Академика Лаврентьева, д. 9.
}

DOI: 10.19163/MedChemRussia2021-2021-65

E-mail: neganova83@mail.ru

Гидроксамовые кислоты являются одним из наиболее перспективных и активно изучаемых классов химических соединений в качестве потенциальных терапевтических агентов [1, 2], в частности, для борьбы с нейропатологиями [3, 4]. В качестве нового подхода к лечению болезни Альцгеймера в данной работе в качестве Сар-группы были использованы фрагменты адамантана и природных терпеновых соединений камфана и фенхана в сочетании с линкерами различной природы с амидной группой. 11 целевых соединений были разработаны, синтезированы и исследованы в комплексе анализов in vitro, in vivo и ex vivo.

В результате in vitro испытаний в качестве наиболее перспективных веществ были выбраны гидроксамовые кислоты 15 и 25, которые эффективно ингибируют HDAC6 и проявляют антиагрегационные свойства в отношении $A \beta$, а также обладают антиоксидантной активностью и не оказывают токсического действия на здоровую культуру клеток НЕК 293. При изучении in vivo нейропротекторного потенциала для гидроксамовой кислоты 15 была обнаружена способность восстанавливать нарушения в обучении и формировании долговременной эпизодической и пространственной памяти трансгенных мышей 5xFAD, моделирующих болезнь Альцгеймера. Кроме того, количественная оценка накоплений А $\beta$ в срезах мозга животных экспериментальных групп выявила значительно более низкое содержание включений А $\beta$ у трансгенных мышей, получавших лечение гидроксамовой кислотой 15.

Полученные результаты подтверждают перспективность синтетического подхода к созданию эффективных полифункциональных нейропротекторных соединений, а гидроксамовая кислота 15, содержащая адамантановый фрагмент, связанный амидной связью с углеводородным линкером, является возможным потенциальным мультитаргетным агентом против болезни Альцгеймера.

\section{Литература}

[1] M. Manal et al., Bioorg Chem. 2016, 67, 18-42.

[2] X. Qiu et al., Prog Neuropsychopharmacol Biol Psychiatry. 2017, 72, 60-72.

[3] K. Xu et al., Oxid Med Cell Longev. 2011, 2011, 143269.

[4] M. Neganova et al., Curr Med Chem. 2020.

$$
-65-
$$

